\title{
Effect of pelagic longline bait type on species selectivity: a global synthesis of evidence
}

\author{
Eric Gilman (1) - Milani Chaloupka (1) Pascal Bach 1 - Hannah Fennell • \\ Martin Hall (1) - Michael Musyl (iD) - Susanna Piovano (D) Francois Poisson • \\ Liming Song $\mathbb{B}$
}

Received: 14 April 2020/Accepted: 7 July 2020/Published online: 3 August 2020

(C) The Author(s) 2020

\begin{abstract}
Fisheries can profoundly affect bycatch species with 'slow' life history traits. Managing bait type offers one tool to control species selectivity. Different species and sizes of marine predators have different prey, and hence bait, preferences. This preference is a function of a bait's chemical, visual, acoustic and textural characteristics and size, and for seabirds the effect on hook sink rate is also important. We conducted a global meta-analysis of existing estimates of the relative risk of capture on different
\end{abstract}

Electronic supplementary material The online version of this article (https://doi.org/10.1007/s11160-020-09612-0) contains supplementary material, which is available to authorized users.

E. Gilman $(\bowtie)$

Pelagic Ecosystems Research Collective, Honolulu, USA

e-mail: FisheriesResearchGroup@gmail.com

M. Chaloupka

Ecological Modelling Services Pty Ltd and Marine Spatial

Ecology Lab, University of Queensland, Brisbane,

Australia

P. Bach · F. Poisson

MARBEC, Université de Montpellier, CNRS, IFREMER,

IRD, Sète, France

H. Fennell

Heriot-Watt University, Edinburgh, UK

M. Hall

Inter-American Tropical Tuna Commission, La Jolla, USA pelagic longline baits. We applied a Bayesian random effects meta-analytic regression modelling approach to estimate overall expected bait-specific catch rates. For blue shark and marine turtles, there were $34 \%$ (95\% HDI: 4-59\%) and 60\% (95\% HDI: 44-76\%) significantly lower relative risks of capture on forage fish bait than squid bait, respectively. Overall estimates of bait-specific relative risk were not significantly different for seven other assessed taxa. The lack of a significant overall estimate of relative capture risk for pelagic shark species combined but significant effect for blue sharks suggests there is species-specific variability in bait-specific catch risk within this group. A qualitative literature review suggests that tunas and

M. Musyl

Pelagic Research Group, Honolulu, USA

S. Piovano

School of Marine Studies, University of the South Pacific, Suva, Fiji

L. Song

Shanghai Ocean University, Shanghai, China 
istiophorid billfishes may have higher catch rates on squid than fish bait, which conflicts with reducing marine turtle and blue shark catch rates. The findings from this synthesis of quantitative and qualitative evidence support identifying economically viable bycatch management measures with acceptable tradeoffs when multispecies conflicts are unavoidable, and highlight research priorities for global pelagic longline fisheries.

Keywords Bait - Bycatch - Longline - Mitigation · Selectivity $\cdot$ Tuna

\section{Introduction}

Pelagic longlines are one of the main fishing methods used to catch tuna and 'tuna-like' species (Scombroidei) and billfishes (Xiphioidei) (SPC 2019; ISSF 2020). Tuna fisheries are of great socioeconomic importance due to the high economic value and extensive international trade of tuna products. Tunas and related species account for over $9 \%$ of total marine fisheries catch, are the fifth most valuable globally traded fishery product, and make up 9\% of the $\$ 164$ billion value of internationally traded seafood products (FAO 2020).

Mortality in pelagic marine fisheries is the main driver of reductions in body sizes and abundances of pelagic apex predators, including target stocks and incidentally caught species, although there is disagreement over the magnitude of these declines (Baum et al. 2003; Myers and Worm 2003; Burgess et al. 2005; Hampton et al. 2005; Ward and Myers 2005; Sibert et al. 2006). The fishing mortality of large, highly migratory pelagic predators of high trophic levels (TL > 4.0) modifies trophic food web structure and processes and functionally linked systems (Pace et al. 1999; Cox et al. 2002; Ward and Myers 2005; Baum and Worm 2009; Polovina et al. 2009). Fisheries that target tuna and tuna-like species, billfishes and other relatively fecund species can have large impacts on incidentally caught species with lower reproduction rates and other 'slow' life history traits. As a result, these higher risk species, including seabirds, marine turtles, marine mammals, elasmobranchs and some teleosts, are vulnerable to increased mortality (Hall et al. 2000; Gilman 2011; Branch et al.
2013). Changes in fishing methods and gear can increase selectivity to mitigate the fishing mortality of at-risk taxa, representing one element of managing fisheries through an ecosystem approach, sustaining a desired state of an ecosystem, in part, by distributing fishing mortality across ecosystem components at sustainable levels according to intrinsic production capacities (Hall 1996; Gilman 2011; Garcia et al. 2012).

Of numerous variables demonstrated to significantly affect catch and survival rates in pelagic longline fisheries, four terminal tackle gear components have been the focus of research and management measures to mitigate the bycatch of species of conservation concern. These gear components are hook shape, narrowest hook width, leader material and bait type (Clarke et al. 2014; Gilman and Hall 2015; Gilman and Huang 2017; Hall et al. 2012, 2017; Gilman et al. 2016b, 2018). Despite this focus, there remains limited understanding of single-factor effects of pelagic longline bait type for most taxonomic groups, including whether there are multispecies conflicts from the use of certain bait types, as demonstrated, for example, for longline hook shape and the time-of-day and depth of longline fishing (Gilman and Hall 2015; Reinhardt et al. 2017; Gilman et al. 2016b, 2019).

To address this priority research gap, speciesspecific overall expected relative risk of higher catch rates by pelagic longline bait type was estimated using a Bayesian random-effects meta-analytical regression modelling approach. The validity of a hypothesis cannot be based on a single study: results can vary between studies because a single study can be contextspecific, where results may be affected by the specific conditions, such as the study area, study period, species involved, and environmental conditions that prevent the results from that single study from being applicable under different conditions. Furthermore, a single study may have low power and fail to find a meaningful result due to too small a sample size. Due to larger sample sizes plus the number of independent studies, correctly designed meta-analyses can provide estimates with increased precision and accuracy over single studies, with increased statistical power to detect real effects (Borenstein et al. 2009; Koricheva et al. 2013; Vetter et al. 2013). By synthesizing estimates from a mixture of independent, small and context-specific studies, pooled estimates from meta- 
analyses are generalizable and hence relevant over diverse settings (Sutton et al. 2000). In addition to the meta-analysis, we undertook a qualitative literature review to compile findings on the effects of pelagic longline bait type on taxon-specific catch risk. Findings from these syntheses of quantitative and qualitative evidence have implications for bycatch management in global pelagic longline fisheries, including improved understanding of the relative risks, conflicts as well as mutual benefits within and across taxonomic groups of conservation concern of alternative pelagic longline bait types. The study also highlights research priorities to fill identified data gaps.

\section{Methods}

Data compilation

The study followed PRISMA (preferred reporting items for systematic reviews and meta-analyses) protocols to assemble a dataset suitable for metaanalytic evaluation (Liberati et al. 2009) (Supplemental Material Section S1). Between 1 Oct. 2019 and 1 April 2020, we conducted a two-tiered literature search to compile relevant peer-reviewed and grey literature. A systematic literature search was conducted using Google Scholar, Web of Science, the Western and Central Pacific Fisheries Commission's Bycatch Management Information System online database of references (https://www.bmis-bycatch. org/references), and the Consortium for Wildlife Bycatch Reduction's online database of references (https://www.bycatch.org/) (Supplemental Material Section S1). We then conducted an unstructured literature search by reviewing reference lists and contacting authors of relevant publications and reports from the systematic search to identify additional studies, and posting a query on ResearchGate.net.

We screened the compiled literature to determine which publications could be included in the metaanalysis. To be included, a publication had to:

1. Use at least one squid species (pelagic longline fisheries primarily use Illex spp. which are used whole as bait, and some fisheries use pieces of larger squid species, such as Dosidicus gigas, as bait) and at least one pelagic 'forage' fish species, such as mackerels and species with mackerel-like characteristics (Collette and Nauen 1983), for bait;

2. Report the number of hooks that were baited with forage fishes and the number baited with squids; and

3. Report the number caught on forage fish baited hooks and on squid baited hooks by individual species or by a higher taxonomic group (seabird, marine turtle, marine mammal, shark, ray, billfish, tuna, other teleost).

We refer to all species and higher taxonomic groupings simply as 'species' hereafter for convenience. Due to small sample sizes, records were not included in the study where artificial bait or pieces of large marine species were used for bait (Supplemental Material Section S6).

The systematic literature search identified 28,684 unique publications, of which 22 met the criteria for inclusion in the meta-analysis (Supplemental Material Fig. S1). An additional 12 publications and databases that met the inclusion criteria were compiled through the unstructured search. If data reported in a publication could be split into subsets so that only a single hook shape, hook size and/or leader material was employed in each subset, then these subsets of data were included as separate records in the meta-analysis. To avoid duplication, publications that contained data for the same fishery and periods were integrated into a single record. A total of 34 publications were found in the global literature review that met the inclusion criteria, which provided a total of 112 relative risk estimates, with 21 estimates for marine turtles, 18 for sharks, 13 for blue shark (Prionace glauca), 12 for 'other teleosts' (bony fishes other than tunas and billfishes), 10 for tunas, 10 for billfishes, 9 for swordfish (Xiphias gladius), 9 for rays, 7 for seabirds and 3 for marine mammals (Supplemental Material Table S1).

\section{Statistical modelling approach}

We used a random-effects meta-analytical regression modelling approach (van Houwelingen et al. 2002; Higgins et al. 2009) to estimate bait-specific catch rates for: marine turtles, sharks, blue shark, other teleosts, tunas, billfishes, swordfish, rays and seabirds. Sample sizes were inadequate for marine mammals. 
In order to compare bait-specific catch rates for each species in a meta-analytical approach, we need a standardized study-specific summary metric-also known as the effect size (Nakagawa et al. 2015). Study-specific log relative risk was used as the species-specific summary or effect size metric (Nakagawa and Santos 2012) of being caught on either of two bait types (forage fish and squid) accounting for the precision of each estimate. This log risk ratio was the effect size metric used by Gilman et al. (2016b) in a comprehensive meta-regression analysis of shark catch rates on various hook types. We calculated the study-specific log risk ratios for each species using the escalc () function in the metafor package for $\mathrm{R}$ (Viechtbauer 2010). The commonly used continuity correction for zero counts of adding 0.5 (Higgins and Green 2011) is the default in the escalc ( ) function, which we used to calculate the effects size metric. This is, however, not necessary in a fully Bayesian approach (Günhan et al. 2020) since a suitable prior is used in that inference framework (Tuyl et al. 2008).

Prior to further modelling, we explored potential publication bias (Murtaugh 2002; Nakagawa and Santos 2012) using those calculated effect sizes and a contour-enhanced funnel plot (Peters et al. 2008) of the model predicted estimates for each species using the metafor package for R (Viechtbauer 2010). There was no evidence of potential publication bias for any of the assessed species that could be identified by funnel plot asymmetry based on a random-effects meta-analytic model fitted within a frequentist inference framework (see Fig. S2 for an example of a contour-enhanced funnel plot for sharks).

Bayesian inference is considered especially useful for small sample situations and especially so for small sample meta-analysis (Sutton et al. 2001; McNeish 2016; Seide et al. 2019). We fitted Bayesian randomeffects regression models with Gaussian likelihood (Kruschke and Liddell 2018) to the calculated effect sizes (and standard deviation) for each species using the Stan computation back-end (Carpenter et al. 2017) via the brms interface for $\mathrm{R}$ (Bürkner 2017). This is also known as a normal-normal hierarchical model (Seide et al. 2019, Günhan et al. 2020). The speciesspecific samples sizes were too small to consider potentially informative covariates. We therefore only used random-effects models rather than fixed- or mixed-effects or meta-regression models that have been used in other recent ecological meta-analyses (e.g., Gilman et al. 2016b; Pfaller et al. 2018; Musyl and Gilman 2019).

We used weakly informative regularizing priors (Gelman et al. 2008; McNeish 2016) to derive more robust estimates of the study-specific parameter uncertainty. All models were fit with 4 chains with 2500 iterations per chain after a warm-up (or burn-in) of 1000 iterations. Thus, the posterior for each estimate comprises 10,000 posterior samples or draws that are used to derive the quantile-based uncertainty estimates (also known as equal-tailed credible intervals in Bayesian statistics parlance; Kruschke and Liddell 2018).

The fitted normal-normal hierarchical model to the study-specific estimates for each species were also used to derive the overall or pooled log risk ratio and measure of uncertainty. We then summarized the species-specific results in a forest plot of the studyspecific posterior densities to display the modelpredicted mean posterior estimates and $95 \%$ credible intervals (see Schild and Voracek 2015 for a useful overview of various forms of forest plots). We also back-transformed the pooled log risk ratio for each species using the transform-then-summarize posterior samples approach since summary metrics are not transform invariant (Wang et al. 2018). We used these back-transformed posterior samples to calculate the percent risk reduction in bait-specific catch risk. Here we used the highest posterior density interval (HDI) as our measure of uncertainty, which is the shortest credible interval, as opposed to the often used equaltailed (quantile-based) credible interval (Kruschke and Liddell 2018). The HDIs were summarized from the posterior samples for each species meta-analytic model fit using the tidybayes package for R (Kay 2019).

We used the ggplot2 package for $\mathrm{R}$ for all data visualization (Wickham 2016). For some species (tunas, sharks) we also included the observed studyspecific effect size for comparison to illustrate why the model-based estimates are used to account for studies of varying precision-study-specific estimates with low precision are shrunk towards the pooled estimate while the estimates with high precision show little if any shrinkage. We also fitted a binomial-normal hierarchical model to the blue shark and tuna effects sizes using the MetaStan interface to Stan (Günhan et al. 2020) that does not require any zero count continuity correction, but this gave very similar results 
to the same species-specific normal-normal hierarchical model and so is not considered further.

The meta-analyses used a simple random effects structure that addressed each study as independent within each species. However, some studies used in our species-specific models were undertaken by the same author(s), possibly resulting in correlated effects between studies by the same authors or research group (Konstantopoulos 2011). Gilman et al. (2016b) addressed this issue using a three-level hierarchical mixed-effects model in their multi-species metaregression modelling of pelagic longline catch rates for sharks. But there were too few species-specific studies in this bait-specific catch dataset to support a more complex multilevel or random effects structure.

\section{Results}

Figures 1, 2 and S3-S9 are forest plots summarizing the model-predicted log risk ratios and the estimated pooled random effect. All 112 records from the studies were uniquely labelled to be able to support any form of random effects structures, identified in Table S1. These labels are referenced in Figs. 1, 2 and S3-S9 for records from studies with more than 1 record. The forest plots for tunas (Fig. S3) and pelagic sharks (Fig. S7) also show the observed effects sizes for comparison with the model-predicted (or shrinkage) estimates. For example, the observed log risk ratio for tunas sourced from Januma et al. (1999) was 0.6, while the shrinkage estimate from the random effect model was 0.4 , where the difference in the estimates reflects the poor precision of the observed effect size.

Table 1 presents the back-transformed posterior risk ratios and percent risk reduction in bait-specific catch risk for two species with significant pooled random effects estimates of relative risk. For marine turtles, the pooled log relative risk estimate was -0.95 (95\% credible interval: -1.37 to -0.57 ) (Fig. 1). When back-transformed, the pooled random effects estimate was 0.39 (95\% HDI: 0.24 to 0.56 ) (Table 1). Marine turtle catch risk on squid bait was 2.6 times the catch risk on fish bait and there was a $60 \%$ (95\% HDI: $44 \%$ to $76 \%$ ) lower catch risk on fish than on squid bait (Table 1). For blue sharks, the overall log relative risk estimate was $-0.44(95 \%$ credible interval: -0.92 to -0.05 ) (Fig. 2). The back-transformed overall random effects estimate was
0.66 (95\% HDI: 0.41 to 0.96 ). Blue shark catch risk on squid bait was 1.5 times that of fish bait and there was a $34 \%$ (95\% HDI: $4 \%$ to $59 \%$ ) lower catch risk on fish bait than on squid bait (Table 1). There was significant between-study heterogeneity evident for both marine turtles and blue sharks (see tau estimates in the captions of Figs. 1 and 2) that was not accounted for by the random-effects model. Nonetheless, the posterior probability of the overall effect being $<0$ was $100 \%$ for marine turtles (Fig. 1) and $98 \%$ for blue sharks (Fig. 2). The overall random effects estimate of relative risk were not significant for the other assessed species (Figs. S2-S8).

\section{Discussion}

Bait type effects on species selectivity

For most species and species groups, sample sizes of the number of studies compiled for the meta-analyses were relatively small (Supplemental Material Table S1). Table 2 reviews published findings of significant effects of pelagic longline bait type on species-specific catch risk. Sample sizes of speciesspecific published findings of significant effects of longline bait type were also relatively small (Table 2). It is a priority to conduct additional research to increase sample sizes to enable more robust metaanalyses with increased precision and power in pooled estimates. This is a research priority because information on species-specific catch risk by bait type is needed to identify multispecies conflicts. As is the case for pelagic longline hook shape, fishing depth and time-of-day of fishing (Reinhardt et al. 2017; Gilman et al. 2016b, 2019), there may also be conflicting species- and taxa-specific catch risk responses to longline bait type. A transition to an integrated bycatch assessment and management framework is needed, where relative risks and conflicts from alternative bycatch management measures can be evaluated through a decision support tool and accounted for in fisheries decision-making processes. This integrated bycatch framework would enable managers to select measures with intentional and acceptable tradeoffs to best meet objectives when conflicts are unavoidable (Gilman et al. 2019).

A desirable significant reduction in pelagic longline catch risk of marine turtles with fish relative to squid 


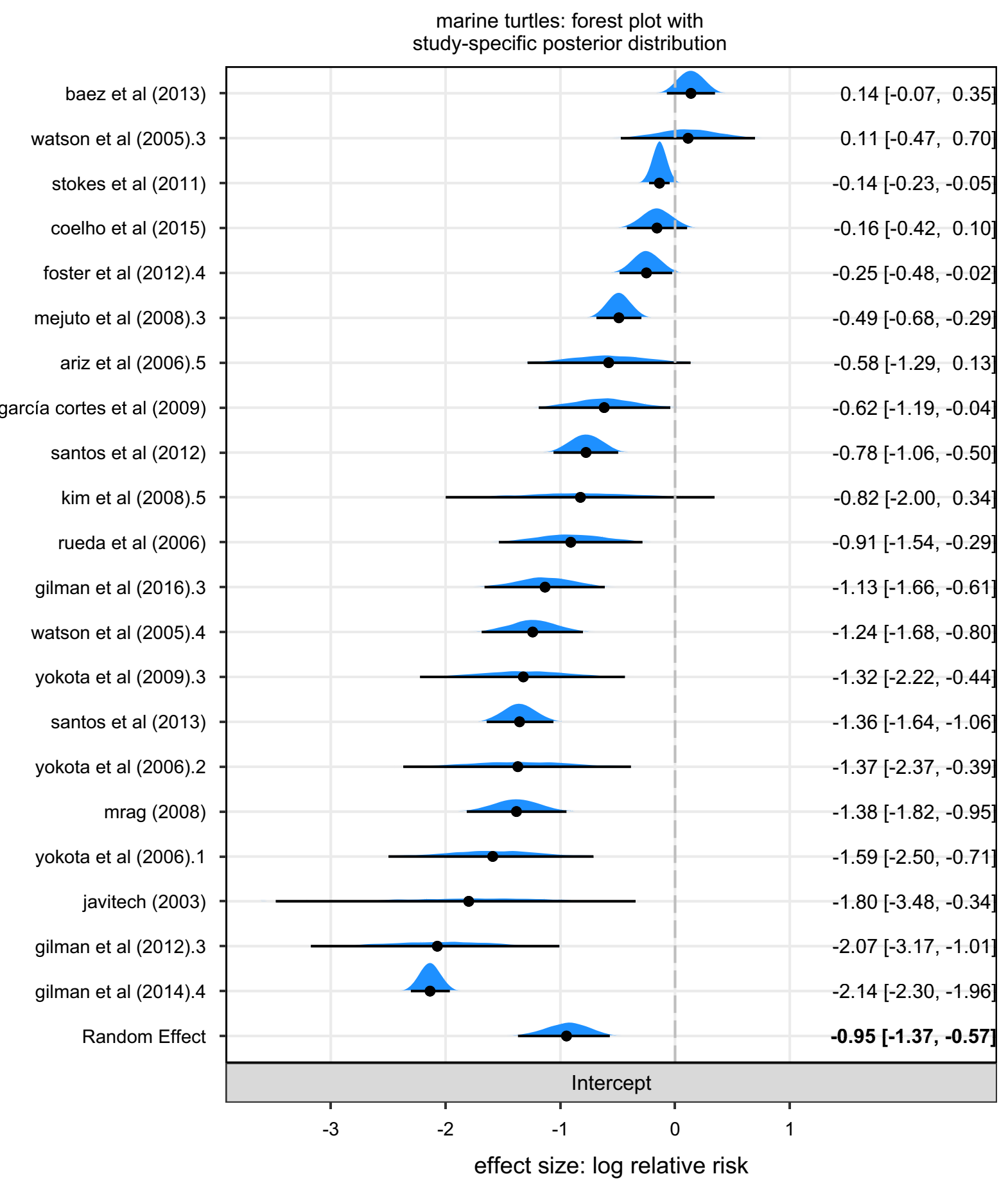

Fig. 1 Model-predicted log risk ratios for bait-specific catch rates derived from 21 study-specific effect sizes for marine turtles. The shrinkage estimates were derived using a Bayesian random-effects meta-analytic model with Gaussian likelihood. Polygon $=$ density of the posterior draws (the effective sample size $=10 \mathrm{k}$ ), horizontal line $=95 \%$ credible interval of the posterior draws, solid dot $=$ mean of the posterior draws shrunk towards the Random Effect estimate that is the pooled or overall log risk ratio for all 21 studies, dashed vertical line indicates no bait-specific effect with shrinkage estimates to the left of this line reflecting a lower marine turtle catch rate on pelagic forage fish bait than on squid bait. Heterogeneity (tau) $=0.81(95 \%$ HDI: 0.49-1.16). The loggerhead sea turtle was the predominant turtle species caught in 12 of the 21 records 


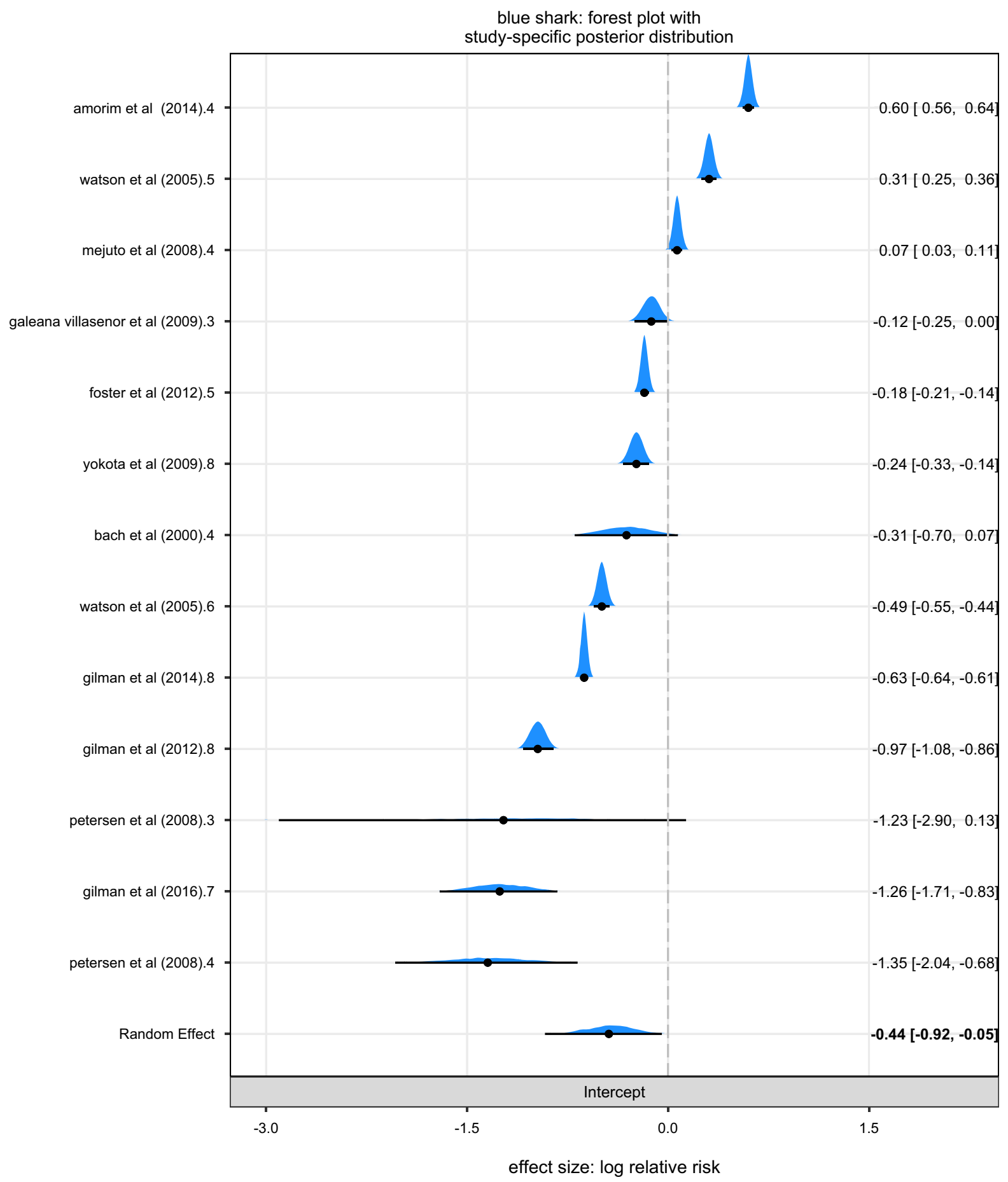

bait, which has been relatively well studied (Table 2; Gilman and Huang, 2017) and implemented in management measures (e.g., Gilman et al. 2014b), produces a mutually beneficial significant reduction in catch risk of blue sharks. The lack of a significant pooled risk ratio for combined pelagic shark species but a significant risk ratio for blue sharks suggests that there is species-specific variability in bait-specific 
४Fig. 2 Model-predicted log risk ratios derived from 13 studyspecific effect sizes for blue sharks sourced from 11 publications for bait-specific catch rates. The shrinkage estimates were derived using a Bayesian random-effects meta-analytic model with Gaussian likelihood. Polygon $=$ density of the posterior draws, horizontal line $=95 \%$ credible interval of the posterior draws, solid dot $=$ mean of the posterior draws shrunk towards the Random Effect estimate that is the pooled or overall log risk ratio for all 13 studies, dashed vertical line indicates no baitspecific effect with shrinkage estimates to the left of this line reflecting a lower blue shark catch rate on pelagic forage fish bait than on squid bait. Heterogeneity (tau) $=0.74$ (95\% HDI: $0.41-1.19)$

catch risk for this group. This may be due to speciesspecific differences in prey preferences, including variability in diet specialization (some species may be generalists, diversifying their diet depending on what prey are available, others may have relatively specialized diets), local prey availability and differences in predatory behavior (Smith et al. 2008; Biton-Porsmoguer et al. 2017; Bizarro et al. 2017; Crooks 2020).

From the qualitative literature review, compiled findings suggest that tunas and istiophorid billfishes may have higher catch rates on squid relative to forage fish bait (Table 2). If these findings are accurate, then for fisheries targeting these species, this presents a conflict between using fish bait to reduce catch risk of marine turtles and blue sharks. This may also present a conflict between maximizing catches of target tunas and mitigating the catch of overexploited stocks of incidentally caught tunas and istiophorid billfishes (e.g., southwest Pacific striped marlin Kajikia audax, Ducharme-Barth et al. 2019; Pacific bluefin tuna Thunnus orientalis, ISC 2018).
Albatrosses were the main species in 5 of the 7 records included in the seabird meta-analytic regression model, which exhibited a non-significant estimated pooled log risk ratio of lower catch risk on fish bait relative to squid (Supplemental Material Fig. S9). The compiled findings of the qualitative review showed species-specific variability in bait type effects on catch risk of various non-albatross seabird species. The use of primarily live fish bait and dead squid bait very likely explains the higher seabird catch risk on fish bait in Trebilco et al. (2010), where after setting, once the branchline becomes taut, the live bait may struggle, swimming erratically in variable directions, reducing the hook's sink rate relative to dead bait, prolonging access to seabirds (Gilman et al. 2005; Robertson et al. 2010). With this record from Trebilco et al. (2010) removed from the seabird meta-analytic model, there was still a non-significant estimated pooled log risk ratio. The small number of studies and small within study sample size of seabird records for the meta-analysis (Supplemental Material Table S1, Fig. S9) as well as only three studies identified, each with small sample sizes, that reported significant effects of bait type on seabird catch risk (Table 2), highlights the paucity of studies on longline bait effects on seabird catch risk and is a high research priority.

Bait type underlying mechanisms for effect on catch risk

Different species and sizes of pelagic marine predators have different prey preferences and prey speciesspecific predation behavior. The detection, searching

Table 1 Summary of marine turtle and blue shark risk ratio metrics and calculated percent difference between catch on fish and squid bait

\begin{tabular}{lllllll}
\hline Taxon & \multicolumn{2}{l}{ Risk ratio } & & \% risk difference & No. of records \\
\cline { 2 - 3 } & Posterior mean & $95 \%$ HDI & & Posterior mean & $95 \%$ HDI \\
\hline Marine turtles $^{\mathrm{a}}$ & 0.39 & $(0.24,0.56)$ & & -60 & $(-76,-44)$ & 21 \\
Blue shark $^{\mathrm{b}}$ & 0.66 & $(0.41,0.96)$ & & -34 & $(-59,-4)$ & 13 \\
\hline
\end{tabular}

a Javitech (2003), Watson et al. (2005), Ariz et al. (2006), Rueda et al. (2006), Kim et al. (2007, 2008), Mejuto et al. (2008), GarcíaCortés et al. (2009), Yokota et al. (2006, 2009), Stokes et al. (2011), Foster et al. (2012), Baez et al. (2013), Santos et al. (2012, 2013), Coelho et al. (2015) and Gilman et al. (2007, 2012, 2014a, 2016a)

${ }^{b}$ Abbes et al. (1996), ECOTAP (1998), Bach et al. (2000), Watson et al. (2005), Mejuto et al. (2008), Petersen et al. (2008), GaleanaVillasenor et al. (2009), Yokota et al. (2009), Foster et al. (2012), Amorim et al. (2014) and Gilman et al. (2007, 2012, 2014a, 2016a) 
Table 2 Effects of pelagic longline bait type (mackerel-like forage fish species vs. squid species) on taxon-specific catch risk

\begin{tabular}{|c|c|c|}
\hline Taxon & $\begin{array}{l}\text { No. publications } \\
\text { significantly higher } \\
\text { catch risk on: }\end{array}$ & Citations \\
\hline \multicolumn{3}{|l|}{ Tunas } \\
\hline \multirow[t]{2}{*}{ Bigeye tuna (Thunnus obesus) } & Squid: $3^{\mathrm{a}}$ & $\begin{array}{l}\text { Watson et al. (2005), Coelho et al. (2012), Foster } \\
\text { et al. (2012) and Amorim et al. (2014) }\end{array}$ \\
\hline & Fish: 1 & Shomura (1955) \\
\hline Albacore tuna ( $T$. alalonga) & Squid: 3 & $\begin{array}{l}\text { Coelho et al. (2012), Foster et al. (2012) and Amorim } \\
\text { et al. (2014) }\end{array}$ \\
\hline Yellowfin tuna (T. albacares) & Squid: 3 & $\begin{array}{l}\text { Coelho et al. (2012), Amorim et al. (2014) and } \\
\text { Fernandez-Carvalho et al. (2015) }\end{array}$ \\
\hline Combined tuna species & Squid: 1 & Gilman et al. (2007) \\
\hline \multicolumn{3}{|l|}{ Billfishes } \\
\hline \multirow[t]{2}{*}{ Swordfish } & Squid: 4 & $\begin{array}{l}\text { Broadhurst and Hazin (2001), Coelho et al. (2012), } \\
\text { Amorim et al. (2014) and Fernandez-Carvalho et al. } \\
\text { (2015) }\end{array}$ \\
\hline & Fish: $4^{\mathrm{a}, \mathrm{b}}$ & $\begin{array}{l}\text { Watson et al. (2005), Gilman et al. (2007), García- } \\
\text { Cortés et al. (2009), Baez et al. (2010) and Foster } \\
\text { et al. (2012) }\end{array}$ \\
\hline \multirow[t]{2}{*}{ White marlin (Kajikia albidus) } & Squid: 2 & Coelho et al. (2012) and Amorim et al. (2014) \\
\hline & Fish: 1 & Fernandez-Carvalho et al. (2015) \\
\hline Atlantic blue marlin (Makaira nigricans) & Squid: 1 & Amorim et al. (2014) \\
\hline Indo-Pacific sailfish (Istiophorus platypterus) & Squid: 1 & Coelho et al. (2012) \\
\hline Combined istiophorid billfishes & Squid: 1 & García-Cortés et al. (2009) \\
\hline \multicolumn{3}{|l|}{ Other teleosts } \\
\hline Dolphinfish (Coryphaena hippurus) & Squid: 2 & $\begin{array}{l}\text { Galeana-Villasenor et al. (2009) and Amorim et al. } \\
\text { (2014) }\end{array}$ \\
\hline Escolar (Lepidocybium flavobrunneum) & Squid: 1 & Fernandez-Carvalho et al. (2015) \\
\hline Lancetfish (Alepisaurus ferox) & Fish: 1 & Amorim et al. (2014) \\
\hline Ocean sunfish (Mola mola) & Squid: 1 & Coelho et al. (2012) \\
\hline $\begin{array}{l}\text { Combined opah (Lampris guttatus), wahoo } \\
\text { (Acanthocybium solandri) and dolphinfish }\end{array}$ & Squid: 1 & Gilman et al. (2007) \\
\hline \multicolumn{3}{|l|}{ Sharks } \\
\hline \multirow[t]{2}{*}{ Blue shark } & Squid: $4^{\mathrm{a}}$ & $\begin{array}{l}\text { Watson et al. (2005), Petersen et al. (2008, 2009), } \\
\text { Galeana-Villasenor et al. (2009) and Foster et al. } \\
\text { (2012) }\end{array}$ \\
\hline & Fish: 2 & Coelho et al. (2012) and Amorim et al. (2014) \\
\hline \multirow[t]{2}{*}{ Shortfin mako shark (Isurus oxyrinchus) } & Fish: 4 & $\begin{array}{l}\text { Mejuto et al. (2008), Coelho et al. (2012), Foster et al. } \\
\text { (2012) and Amorim et al. (2014) }\end{array}$ \\
\hline & Squid: 2 & Petersen et al. $(2008,2009)$ \\
\hline \multirow[t]{2}{*}{ Smooth hammerhead shark (Sphyrna zygaena) } & Fish: 2 & Coelho et al. (2012) and Amorim et al. (2014) \\
\hline & Squid: 1 & Fernandez-Carvalho et al. (2015) \\
\hline \multirow[t]{2}{*}{ Silky shark (Carcharhinus falciformis) } & Fish: 1 & Coelho et al. (2012) \\
\hline & Squid: 1 & Galeana-Villasenor et al. (2009) \\
\hline Bigeye thresher shark (Alopias superciliosus) & Fish: 1 & Coelho et al. (2012) \\
\hline Crocodile shark (Pseudocarcharias kamoharai) & Squid: 1 & Coelho et al. (2012) \\
\hline Longfin mako shark (I. paucus) & Squid: 1 & Coelho et al. (2012) \\
\hline Porbeagle shark (Lamna nasus) & Fish: 1 & Foster et al. (2012) \\
\hline
\end{tabular}


Table 2 continued

\begin{tabular}{|c|c|c|}
\hline Taxon & $\begin{array}{l}\text { No. publications } \\
\text { significantly higher } \\
\text { catch risk on: }\end{array}$ & Citations \\
\hline \multicolumn{3}{|l|}{ Rays } \\
\hline \multirow[t]{2}{*}{ Manta rays (Myliobatidae) } & Squid: 1 & Coelho et al. (2012) \\
\hline & Fish: 1 & Amorim et al. (2014) \\
\hline Pelagic stingray (Pteroplatytrygon violacea) & Squid: 1 & Coelho et al. (2012) \\
\hline \multicolumn{3}{|l|}{ Marine turtles } \\
\hline Loggerhead (Caretta caretta) & Squid: $11^{\mathrm{a}, \mathrm{b}, \mathrm{c}, \mathrm{d}}$ & $\begin{array}{l}\text { Watson et al. (2005), Gilman et al. (2007), Mejuto } \\
\text { et al. (2008), MRAG (2008), García-Cortés et al. } \\
\text { (2009), Yokota et al. (2009), Baez et al. (2010), } \\
\text { Stokes et al. (2011), Foster et al. (2012), Piovano } \\
\text { et al. (2012), Santos et al. (2013) and Swimmer } \\
\text { et al. (2017) }\end{array}$ \\
\hline Leatherback (Dermochelys coriacea) & Squid: $5^{\mathrm{a}}$ & $\begin{array}{l}\text { Watson et al. (2005), Gilman et al. 2007), Foster et al. } \\
\text { (2012), Santos et al. (2012, 2013) and Swimmer } \\
\text { et al. (2017) }\end{array}$ \\
\hline Olive ridley (Lepidochelys olivacea) & Squid: 1 & Santos et al. (2012) \\
\hline $\begin{array}{l}\text { Combined hard-shelled loggerhead, olive Ridley } \\
\text { and kemp's ridley (L. kempii) sea turtles }\end{array}$ & Squid: 1 & Coelho et al. (2015) \\
\hline \multicolumn{3}{|l|}{ Marine mammals } \\
\hline Risso's dolphin (Grampus griseus) & Squid: 1 & Garrison (2007) \\
\hline \multicolumn{3}{|l|}{ Seabirds } \\
\hline White-chinned petrel (Procellaria aequinoctialis) & Squid: 1 & Gonzalez et al. (2012) \\
\hline Flesh-footed shearwater (Puffinus carniepes) & Fish: 1 & Trebilco et al. (2010) \\
\hline $\begin{array}{l}\text { Combined seabirds, comprised of: gulls (Larus } \\
\text { spp.), greater shearwater ( } P \text {. gravis), other } \\
\text { shearwaters (Procellariidae), northern gannet } \\
\text { (Morus bassanus) }\end{array}$ & Fish: 1 & Li et al. (2012) \\
\hline
\end{tabular}

${ }^{\mathrm{a}}$ Findings reported by both Foster et al. (2012) and Watson et al. (2005) are included as a single record: a subset of the database analyzed by Foster et al. (2012) had been analyzed by Watson et al. (2005)

${ }^{b}$ Pieces of blue shark were used as a small component of a mix of primarily forage fish species being used for bait in Baez et al. (2010), who compared marine turtle catch in sets using a mix of squid and fish bait versus in sets using only fish bait

${ }^{\mathrm{c}}$ Stokes et al. (2011) studied captive loggerhead sea turtles to assess the effect of bait type on the odds of having an entire hook and crimp enter their mouth as an indicator of catch risk

${ }^{\mathrm{d}}$ Piovano et al. (2012) studied the effect of bait type on captive loggerhead sea turtles biting behavior (opening mouth to bite a sack containing bait)

and attack/feeding behavior for different prey is dictated by a prey's chemical, visual (e.g., size, shape, color and movement) and acoustic characteristics (Lokkeborg and Bjordal 1992; Hart 1993; Broadhurst and Hazin 2001; Constantino and Salmon 2003; Ward and Myers 2007; Ward 2008; Yokota et al. 2009; Piovano et al. 2004, 2012, 2013; Lokkeborg et al. 2014; Warraich 2014). Texture may also influence pelagic predators' predation behavior as has been observed for some demersal fishes (Lokkeborg et al. 2014). Due to differences in bait species and the condition of the bait, there may also be differences in the release rate of chemical attractants and in the duration of retention on hooks (Shomura 1955; Løkkeborg and Johannessen 1992). For example, there is higher hook retention of squid than forage fish species (Shomura 1955; Broadhurst and Hazin 2001; Ward and Myers 2007). The longer the release of chemical attractants and higher the hook retention rate of a bait type, the higher the catch risk.

If rates of bait depredation vary by bait type, then this could reduce the accuracy of estimates of the 
effect of bait type on species-specific catch risk. Cetaceans, sharks, seabirds and some teleosts are the main species that remove baits from pelagic longline gear, while squids and crustaceans can partially depredate pelagic longline baits (Brothers 1991; Gilman et al. 2006, 2008; Hamer et al. 2012). For example, if blue sharks have a higher depredation rate of squid bait relative to forage fish bait, then this would result in overestimating other species' relative risk of capture on fish relative to squid bait due to squiddepredated baitless hooks being counted as available squid-baited hooks. This is similar to how gear saturation can result in underestimates of abundance when interpreting pelagic longline nominal catch rates (Ward 2008; Kuriyama et al. 2019).

For some pelagic predators, the size of the species used for bait can affect their catch risk. The larger the bait, the larger an organism's mouth dimensions need to be to fit it in its mouth (Erzini et al. 1997; Yokota et al. 2012; Gilman and Huang 2017; Gilman et al. 2018). As a result, for species that tend to be caught by ingesting a baited hook, the larger the bait, the lower the relative catchability of smaller species and of smaller length classes within a species (CortezZaragoza et al. 1989; Lokkeborg and Bjordal 1992; Cooke et al. 2005; Bach et al. 2008; Curran and Beverly 2012; Gilman et al. 2018). This is consistent with observations that the mean as well as the maximum size of prey increases with increasing predator size (Scharf et al. 2000; Bachiller and Irigoien 2013). As predators grow, so do the dimensions of their mouths (although this growth may be allometric). This, along with improved vision, digestion, swimming, regional endothermy and other attributes enable larger predators to catch larger prey (Juanes 1994; Kaiser and Hughes 1993), which in turn may affect preferences for certain prey sizes. However, for species that tend to be captured via foul hooking in the body or entanglement, such as thresher sharks and leatherback sea turtles (Aalbers et al. 2010; Curran and Beverly 2012; Epperly et al. 2012; Gilman and Huang 2017; Gilman et al. 2018; Warraich et al. 2020), bait size is expected to have a smaller effect on catch risk relative to species that are predominantly caught by ingesting hooks.

In addition, the relative difficulty to remove a bait type from a hook may affect the catch risk of seabirds, hard-shelled marine turtles and other species that bite their prey, unlike most teleosts which suck in and swallow their prey, and leatherback sea turtles and some species of sharks that tend to get caught by becoming foul-hooked in the body or entangled. Captive loggerhead sea turtles tore pieces of fish bait off in small bites or stripped the entire fish bait from the hook, but tended to ingest an entire squid bait and hook in a single gulp, perhaps because the squid is more rubbery in texture and difficult to tear, and because the squid bait shields the hook, making it difficult to see and feel the hook (Watson et al. 2005; Stokes et al. 2011; Parga et al. 2015). Similarly, squid bait may be more difficult for seabirds to remove from hooks relative to fish bait, resulting in a higher degree of competition with other seabirds and increased risk taking and concomitant catch risk during scavenging (Gilman et al. 2014b).

The effect of bait type on baited hook sink rate is an additional factor that may explain differences in seabird catch risk. A bait's sink profile (i.e., how linear the sink profile is) and stiffness may affect a baited hook's sink rate (Brothers et al. 1995; Robertson and van den Hoff 2010). If species of fish with swim bladders are used for bait, if the bladders are not punctured, then this can contribute to slower sink rates (Brothers et al. 1995, 1999). Small fish species and squid species had similar and non-significantly different sink rates during an at-sea trial, but squid had significantly slower sink rates than fish bait in a tank trial (Robertson and van den Hoff 2010). The use of live bait can also result in lower sink rates of baited hook relative to using dead baits, which, discussed in the previous section, likely explains why the modeled estimate for Trebilco et al. (2010) was the only record showing a significantly higher catch risk on fish relative to squid bait (Fig. S9).

\section{Conclusions and research priorities}

Fisheries that target relatively fecund species such as tunas can have large impacts on incidentally caught species that, due to their lower reproduction rates and other 'slow' life history traits, are relatively vulnerable to increased mortality (Hall et al. 2000; Gilman 2011; Branch et al. 2013). Managing pelagic longline bait type offers one tool to control species selectivity. We conducted a synthesis of quantitative and qualitative evidence. Findings contribute to identifying 
economically viable bycatch management measures and research priorities for global pelagic longline fisheries.

This global meta-analysis of existing estimates of the relative risk of capture on different pelagic longline bait types found significantly lower relative risks of capture on pelagic forage fish bait compared with squid bait for marine turtle species combined as well as for blue sharks. Hence, using forage fish instead of squid for pelagic longline bait mutually benefits these species. However, the qualitative literature review suggests tunas and istiophorid billfishes have significantly higher catch rates on squid relative to forage fish bait, which are important market species in some pelagic longline fisheries. This presents a conflict with managing bait type to reduce marine turtle and blue shark catch rates.

For most species and higher taxonomic groupings, sample sizes of number of studies compiled for the meta-analyses were relatively small. It is a research priority to conduct more studies to enable robust metaanalyses of bait type effects on catch risk for individual species and higher taxonomic groupings. The finding of a significant random effect estimate of the bait-specific overall relative risk ratio for blue sharks but not for pelagic shark species combined suggests that the effect of bait type on catch risk is variable for different pelagic shark species. The group marine mammals had the smallest sample size with only 3 studies, each with small numbers of captured marine mammals. Because cetacean catch risk is due both to depredation of bait and catch (Gilman et al. 2006), managing bait type might have a smaller effect on their catch rates than for other groups. This again highlights the need for sufficient sample sizes to support species-specific meta-analyses. With larger sample sizes to support robust meta-analyses, the effect on catch rates the use of different species of forage fishes and species of squids for longline bait could also be estimated. Knowledge of speciesspecific response to bait type is needed to enable managers to account for any multispecies conflicts so that measures managing bait type result in intentional and acceptable tradeoffs.

A related research priority is to investigate potential socioeconomic effects on pelagic longline fisheries from changing bait type. For instance, would it be economically viable for an artisanal fishery that currently catches squid to use as longline bait to replace this quasi-free bait source with purchased fish bait, and would the change in catch rates of market species caused by this change in bait type be viable? Understanding the ecological effects on the stock status of forage fish species, and socioeconomic effects on food security, from increased demand for these species for use as bait by longline fisheries, and estimating the conservation gains to species of conservation concern from reduced longline fishing mortality that could be achieved from changes in bait type, are additional research priorities.

Conducting species-specific meta-analyses of the effect of pelagic longline bait type on at-vessel and post-release survival is an additional research priority (Gilman et al. 2016b; Musyl and Gilman 2019). Supplemental Material Section S5 reviews the underlying mechanisms for the effect of bait type on the risk of mortality, including effects of bait type on anatomical hooking position and size- and sex-selectivity.

No studies were identified that found an artificial bait to be economically viable for use in pelagic longline fisheries (see review in Supplemental Material Section S6). Developing an artificial pelagic longline bait that retains acceptable catch rates of market species but reduces catch risk of species of conservation concern warrants investment in research and development.

Acknowledgements We are grateful to the fisheries scientists who conducted the research and authored the publications compiled and pooled for this meta-analysis. Support for this project was provided by Vulcan Inc., the Pew Fellows Program in Marine Conservation at The Pew Charitable Trusts and The Safina Center Fellowship Program. The views expressed are those of the authors and do not necessarily reflect the views of Vulcan Inc., The Pew Charitable Trusts or The Safina Center. We thank Jose Carlos Báez and Lucia Rueda Ramirez of the Instituto Español de Oceanografia, Andrés González Pizarro of the Chile Instituto de Fomento Pesquero, Rowan Trebilco and Emma Lawrence of CSIRO Australia, and Barry Baker of Latitude 42 Environmental Consultants for contributing information to supplement their publications. This study was adopted in 2019 as a Topic Group by the ICES-FAO Working Group on Fishing Technology and Fish Behavior.

Open Access This article is licensed under a Creative Commons Attribution 4.0 International License, which permits use, sharing, adaptation, distribution and reproduction in any medium or format, as long as you give appropriate credit to the original author(s) and the source, provide a link to the Creative Commons licence, and indicate if changes were made. The images or other third party material in this article are included in the article's Creative Commons licence, unless indicated otherwise in a credit line to the material. If material is not 
included in the article's Creative Commons licence and your intended use is not permitted by statutory regulation or exceeds the permitted use, you will need to obtain permission directly from the copyright holder. To view a copy of this licence, visit http://creativecommons.org/licenses/by/4.0/.

\section{References}

Aalbers S, Bernal D, Sepulveda C (2010) The functional role of the caudal fin in the feeding ecology of the common thresher shark Alopias vulpinus. J Fish Biol 76:1863-1868

Abbes R, Josse E, Bach P, Yen S (1996). Observations Sur L'efficacité Relative de Deux Appâts, Le Hareng et le Calmar, Dans La Pêche des Thonidés à la Palangre Monofilament en Polynésie Française. (Observations on the Relative Effectiveness of Two Baits, Herring and Squid, in the Monofilament Longline Tuna Fishery in French Polynesia). Programme Conjoint EVAAM/IFREMER/ORSTOM. Programme D'Evaluation Des Ressources Marines de la Zone Economique de NouvelleCaledonie: Noumea, New Caledonia

Amorim S, Santos M, Coelho R, Fernandez-Carvalho J (2014) Effects of 17/0 circle hooks and bait on fish catches in a southern Atlantic swordfish longline fishery. Aquat Conserv 25:518-533

Ariz J, Molina A, Ramos M, Santana J (2006) Check list and catch rate data by hook type and bait for bycatch species caught by Spanish experimental longline cruises in the South-western Indian Ocean during 2005. IOTC-2006WPBy-04. Indian Ocean Tuna Commission, Mahé, Seychelles

Bach P, Dagorn L, Misselis C (2000) The role of bait type on pelagic longline efficiency.In: ICES annual science conference theme session J: efficiency, selectivity and impacts of passive fishing gears CM 2000/J:01, International Council for the Exploration of the Sea (ICES), Brugge, Belgium

Bach P, Gamblin C, Lucas V (2008) The effect of bait type on hooking responses of target and non-target species on pelagic longlines: preliminary results from fishing experiments in the Seychelles. West Indian Ocean J Mar Sci 7:151-161

Bachiller E, Irigoien X (2013) Allometric relations and consequences for feeding in small pelagic fish in the Bay of Biscay. ICES J Mar Sci 70:232-243

Baez J, Real R, Macias D, Serna J, Bellido J, Caminas J (2010) Short communication. Captures of swordfish Xiphias gladius Linnaeus 1758 and loggerhead sea turtles Caretta caretta (Linnaeus 1758) associated with different bait combinations in the Western Mediterranean surface longline fishery. J Appl Ichthyol 26:126-127

Baez J, Macias D, Caminas J, Urbina J, Garcia-Barcelona S, Bellido J, Real R (2013) By-catch frequency and size differentiation in loggerhead turtles as a function of surface longline gear type in the western Mediterranean Sea. J Mar Biol Assoc UK 93:1423-1427
Baum J, Worm B (2009) Cascading top-down effects of changing oceanic predator abundances. J Anim Ecol 78:699-714

Baum J, Myers R, Kehler D, Worm B, Harley S, Doherty P (2003) Collapse and conservation of shark populations in the northwest Atlantic. Science 299:389-392

Biton-Porsmoguer S, Banaru D, Boudouresque C, Dekeyser I, Bearez P, Miguez-Lozano R (2017) Compared diet of two pelagic shark species in the northeastern Atlantic Ocean. Vie Milieu 67:21-25

Bizarro J, Carlisle A, Smith W, Cortes E (2017) Diet composition and trophic ecology of northeast Pacific Ocean sharks. Adv Mar Biol 77:111-148

Borenstein M, Hedges L, Higgins J, Rothstein H (2009) Introduction to Meta-analysis. Wiley Press, West Sussex

Branch T, Lobo A, Purcell S (2013) Opportunistic exploitation: an overlooked pathway to extinction. Trends Ecol Evolut 28:409-413

Broadhurst M, Hazin F (2001) Influences of type and orientation of bait on catches of swordfish (Xiphias gladius) and other species in an artisanal subsurface longline fishery off northeastern Brazil. Fish Res 53:169-179

Brothers N (1991) Albatross mortality and associated bait loss in the Japanese longline fishery in the Southern Ocean. Biol Conserv 55:255-268

Brothers N, Foster A, Robertson G (1995) The influence of bait quality on the sink rate of bait used in the Japanese longline tuna fishing industry: an experimental approach. CCAMLR Sci 2:123-129

Brothers N, Cooper J, Lokkeborg S (1999) The incidental catch of seabirds by longline fisheries: worldwide review and technical guidelines for mitigation. FAO Fisheries Circular 937. Food and Agriculture Organization of the United Nations, Rome

Burgess G, Beerkircher L, Cailliet G, Carlson J, Cortes E, Goldman K, Grubbs R, Musick J, Musyl M, Simpfendorfer C (2005) Is the collapse of shark populations in the Northwest Atlantic Ocean and Gulf of Mexico real? Fisheries 30:19-26

Bürkner P (2017) brms: an R package for Bayesian multilevel models using Stan. J Stat Softw 81:1-28

Carpenter B, Gelman A, Hoffman M, Lee D, Goodrich B, Betancourt M, Brubaker M, Guo J, Li P, Riddell A (2017) Stan: a probabilistic programming language. J Stat Softw 76:1-32

Clarke S, Sato M, Small C, Sullivan B, Inoue Y, Ochi D (2014) Bycatch in longline fisheries for tuna and tuna-like species: a global review of status and mitigation measures. FAO Fisheries and Aquaculture Technical Paper 588. Food and Agriculture Organization of the United Nations, Rome

Coelho R, Santos M, Amorim S (2012) Effects of hook and bait on targeted and bycatch fishes in an equatorial Atlantic pelagic longline fishery. Bull Mar Sci 88:449-467

Coelho R, Santos M, Fernandez-Carvalho J, Amorim S (2015) Effects of hook and bait in a tropical northeast Atlantic pelagic longline fishery: part I-incidental sea turtle bycatch. Fish Res 164:302-311

Collette B, Nauen C (1983) Scombrids of the world: an annotated and illustrated catalogue of tunas, mackerels, bonitos and related species known to date. FAO Fisheries Synopsis 
No 125, vol 2. Food and Agriculture Organization of the United Nations, Rome

Constantino M, Salmon M (2003) Role of chemical and visual cues in food recognition by leatherback posthatchlings (Dermochelys coriacea). Zoology 106:173-181

Cooke S, Barthel B, Suski C, Siepker M, Philipp D (2005) Influence of circle hook size on hooking efficiency, injury, and size selectivity of bluegill with comments on circle hook conservation benefits in recreational fisheries. North Am J Fish Mana 25:211-219

Cortez-Zaragoza E, Dalzell P, Pauly D (1989) Hook selectivity of yellowfin tuna (Thunnus albacares) caught off Darigayos Cove, La Union, Philippines. J Appl Ichthyol 5:12-17

Cox S, Essington T, Kitchell J, Martell S, Walters C, Boggs C, Kaplan I (2002) Reconstructing ecosystem dynamics in the central Pacific Ocean, 1952-1998. II. A preliminary assessment of the trophic impacts of fishing and effects on tuna dynamics. Can J Fish Aquat Sci 59:1736-1747

Crooks N (2020) Chondrichthyes diet. In: Vonk J, Shackelford T (eds) Encyclopedia of animal cognition and behavior. Springer, Basel 978-3-319-47829-6

Curran D, Beverly S (2012) Effects of 16/0 circle hooks on pelagic fish catches in three South Pacific albacore longline fisheries. Bull Mar Sci 88:485-497

Ducharme-Barth N, Pilling G, Hampton J (2019) Stock assessment of SW pacific striped marlin in the WCPO. WCPFCSC15-2019/SA-WP-07. Western and Central Pacific Fisheries Commission, Kolonia, Federated States of Micronesia

ECOTAP (1998) Unpublished Data. Etude du Comportement des Thons par l'Acoustique et la Palangre de la Zone Économique Exclusive de Polynésie Française (Study of tuna behaviour using acoustics and fishing in the French Polynesian EEZ). EVAAM, ORSTOM, and IFREMER, Papete, French Polynesia

Epperly S, Watson J, Foster D, Shah A (2012) Anatomical hooking location and condition of animals captured with pelagic longlines: the grand banks experiments 2002-2003. Bull Mar Sci 88:513-527

Erzini K, Goncalves J, Bentes L, Lino P (1997) Fish mouth dimensions and size selectivity in a Portuguese longline fishery. J Appl Ichthyol 13:41-44

FAO (2020) The state of world fisheries and aquaculture 2020. Sustainability in action. Food and Agriculture Organization of the United Nations, Rome

Fernandez-Carvalho J, Coelho R, Santos M, Amorim S (2015) Effects of hook and bait in a tropical northeast Atlantic pelagic longline fishery: part II-Target, bycatch and discard fishes. Fish Res 164:312-321

Foster D, Epperly S, Shah A, Watson J (2012) Evaluation of hook and bait type on the catch rates in the western north Atlantic Ocean pelagic longline fishery. Bull Mar Sci 88:529-545

Galeana-Villasenor I, Galvan-Magana F, Santana-Hernandez H (2009) Pesca con anzuelos en barcos palangreros del Oceano Pacifico mexicano: efectos en la captura y peso de tiburones y otras especies. Rev Biol Mar Oceanogr 44:163-172

Garcia S, Kolding J, Rice J, Rochet M, Zhou S, Arimoto T, Beyer J, Borges L, Bundy A, Dunn D, Fulton E, Hall M,
Heino M, Law R, Makino M, Rijnsdorp A, Simard F, Smith A (2012) Reconsidering the consequences of selective fisheries. Science 335:1045-1047

García-Cortés B, de Urbina J, Ramos-Cartelle A, Mejuto J (2009) Trials with different hooks and bait types in the configuration of the surface longline gear used by the Spanish swordfish (Xiphias gladius) fishery in the Pacific Ocean. Collect Vol Sci Pap ICCAT 64:2469-2498

Garrison L (2007) Interactions between marine mammals and pelagic longline fishing gear. Fish Bull 105:408-417

Gelman A, Jakulin A, Pittau M, Su Y (2008) A weakly informative default prior distribution for logistic and other regression models. Ann Appl Stat 2:1360-1383

Gilman E (2011) Bycatch governance and best practice mitigation technology in global tuna fisheries. Mar Policy 35:590-609

Gilman E, Hall M (2015) Potentially significant variables explaining bycatch and survival rates and alternative data collection protocols to harmonize tuna RFMOs' Pelagic Longline Observer Programmes. Appendix 1. WCPFCSC11-2015/EB-IP-05. https://www.wcpfc.int/system/files/ EB-IP-05\%20LL\%20Obs\%20bycatch\%20data\%

20fields\%20Rev\%201\%2028\%20July.pdf. Western and Central Pacific Fisheries Commission, Kolonia, Pohnpei, Federated States of Micronesia. Accessed 1 April 2020

Gilman E, Huang H (2017) Review of effects of pelagic longline hook and bait type on sea turtle catch rate, anatomical hooking position and at-vessel mortality rate. Rev Fish Biol Fisher 27:43-52

Gilman E, Brothers N, Kobayashi D (2005) Principles and approaches to abate seabird bycatch in longline fisheries. Fish Fish 6:35-49

Gilman E, Brothers N, McPherson G, Dalzell P (2006) Review of cetacean interactions with longline gear. J Cetac Res Manag 8:215-223

Gilman E, Kobayashi D, Swenarton T, Brothers N, Dalzell P, Kinan I (2007) Reducing sea turtle interactions in the Hawaii-based longline swordfish fishery. Biol Conserv 139:19-28

Gilman E, Clarke S, Brothers N, Alfaro-Shigueto J, Mandelman J, Mangel J, Peterson S, Piovano S, Thomson N, Dalzell P, Donoso M, Goren M, Werner T (2008) Shark interactions in pelagic longline fisheries. Mar Policy 32:1-18

Gilman E, Chaloupka M, Read A, Dalzell P, Holetschek J, Curtice C (2012) Hawaii longline tuna fishery temporal trends in standardized catch rates and length distributions and effects on pelagic and seamount ecosystems. Aquat Conserv 22:446-488

Gilman E, Chaloupka M, Wiedoff B, Willson J (2014a) Mitigating seabird bycatch during hauling by pelagic longline vessels. PLoS ONE 9:e84499

Gilman E, Passfield K, Nakamura K (2014b) Performance of regional fisheries management organizations: ecosystembased governance of bycatch and discards. Fish Fish 15:327-351

Gilman E, Chaloupka M, Merrifield M, Malsol N (2016a) Standardized catch and survival rates, and effect of a ban on shark retention, Palau pelagic longline fishery. Aquat Conserv 26:1031-1062

Gilman E, Chaloupka M, Swimmer Y, Piovano S (2016b) A cross-taxa assessment of pelagic longline bycatch 
mitigation measures: conflicts and mutual benefits to elasmobranchs. Fish Fish 17:748-784

Gilman E, Chaloupka M, Musyl M (2018) Effects of pelagic longline hook size on species- and size-selectivity and survival. Rev Fish Biol Fisher 28:417-433

Gilman E, Chaloupka M, Dagorn L, Hall M, Hobday A, Musyl M, Pitcher T, Poisson F, Restrepo V, Suuronen P (2019) Robbing Peter to pay Paul: replacing unintended cross-taxa conflicts with intentional tradeoffs by moving from piecemeal to integrated fisheries bycatch management. Rev Fish Biol Fisher 29:93-123

Gonzalez A, Vega R, Barbieri M, Yáñez E (2012) Determinación de los factores que inciden en la captura incidental de aves marinas en la flota palangrera pelágica chilena. Lat Am J Aquat Res 40:786-799

Günhan B, Röver C, Friede T (2020) Random-effects metaanalysis of few studies involving rare events. Res Synth Methods 11:74-90

Hall M (1996) On bycatches. Rev Fish Biol Fish 6:319-352

Hall M, Alverson D, Metuzal K (2000) By-catch: problems and solutions. Mar Pollut Bull 41:204-219

Hall M, Swimmer Y, Parga M (2012) No "silver bullets", but plenty of options: working with the Eastern Pacific artisanal fishers to reduce sea turtle mortality in fisheries. In: Seminoff J, Wallace B (eds) Sea turtles of the Eastern Pacific Ocean: natural history, conservation challenges, and signs of success. University of Arizona Press, Tucson, pp 136-153

Hall M, Gilman E, Minami H, Mituhasi T, Carruthers E (2017) Mitigating bycatch in tuna fisheries. Rev Fish Biol Fisher 27:881-908

Hamer D, Childerhouse S, Gales N (2012) Odontocete bycatch and depredation in longline fisheries: a review of available literature and of potential solutions. Mar Mamm Sci 28:E345-E374

Hampton J, Sibert J, Kleiber P, Maunder M, Harley S (2005) Decline of Pacific tuna populations exaggerated? Nature 434:E1-E2

Hart P (1993) Foraging in teleost fishes. In: Pitcher T (ed) Behaviour of teleost fishes, 2nd edn. Chapman \& Hall, London, pp 211-235

Higgins J, Green S (2011) Cochrane handbook for systematic reviews of interventions. Version 5.1.0. The Cochrane Collaboration, London

Higgins J, Thompson S, Spiegelhalter D (2009) A re-evaluation of random-effects meta-analysis. J R Stat Soc A 172:137-159

ISC (2018) Stock assessment of Pacific bluefin tuna (Thunnus orientalis) in the Pacific Ocean in 2018. Report of the Pacific Bluefin Tuna Working Group. International Scientific Committee for Tuna and Tuna-like Species in the North Pacific Ocean, Yokohama, Japan

ISSF (2020) Status of the world fisheries for tuna. ISSF Technical Report 2020-12. International Seafood Sustainability Foundation, Washington, DC

Januma S, Kajiwara Y, Miura T, Yamamoto J, Haruyama M (1999) Trial use of artificial bait with tuna longline. Bull Facul Fish Hokkaido Univ 50:71-76

Javitech (2003) Report on sea turtle interactions in the 2002 pelagic (offshore) longline fishery, February 14, 2003.
Canadian Wildlife Service, Environment Canada, Ottawa, Canada

Juanes F (1994) What determines prey size selectivity in piscivorous fishes? In: Stouder D, Fresh K, Feller R (eds) Theory and application in fish feeding ecology. University of South Carolina Press, Columbia, SC, pp 79-100

Kaiser MJ, Hughes RN (1993) Factors affecting the behavioural mechanisms of diet selection in fishes. Mar Behav Physiol 23(1-4):105-118

Kay M (2019) tidybayes: tidy data and geoms for Bayesian models. R package version 1.1.0. R Core Team, Vienna, Austria

Kim S, Moon D, An D, Koh J (2007) Comparison of circle hook and $\mathrm{j}$ hook catch rate for target and bycatch species taken in the Korean tuna longline fishery during 2005-2006. WCPFC-SC 3-EB SWG/WP-11. Western and Central Pacific Fisheries Commission, Kolonia, Federated States of Micronesia

Kim S, Moon D, An D, Hwang S, Kim Y, Bigelow K, Curran D (2008) Effects of hook and bait types on bigeye tuna catch rates in the tuna longline fishery. Korean $\mathrm{J}$ Ichthyol 20:105-111

Konstantopoulos S (2011) Fixed effects and variance components estimation in three-level meta-analysis. Res Synth Methods 2:61-76

Koricheva J, Gurevitch J, Mengersen K (2013) Handbook of meta-analysis in ecology and evolution. Princeton University Press, Princeton

Kruschke J, Liddell T (2018) The Bayesian new statistics: hypothesis testing, estimation, meta-analysis, and power analysis from a Bayesian perspective. Psychon B Rev 25:178-206

Kuriyama P, Branch T, Hicks A, Harms J, Hamel O (2019) Investigating three sources of bias in hook-and-line surveys: survey design, gear saturation, and multispecies interactions. Can J Fish Aquat Sci 76:192-207

Li Y, Browder J, Jiao Y (2012) Hook effects on seabird bycatch in the United States Atlantic pelagic longline fishery. Bull Mar Sci 88:559-569

Liberati A, Altman D, Tetzlaff J, Mulrow C, Gotzsche P, Ioannidis J, Clarke M, Devereaux P, Kleijnen J, Moher D (2009) The PRISMA statement for reporting systematic reviews and meta-analyses of studies that evaluate health care interventions: explanation and elaboration. PLoS Med 6:e1000100

Lokkeborg S, Bjordal A (1992) Species and size selectivity in longline fishing: a review. Fish Res 13:311-322

Løkkeborg S, Johannessen T (1992) The importance of chemical stimuli in bait fishing-fishing trials with presoaked bait. Fish Res 14:21-29

Lokkeborg S, Siikavuopio S, Humborstad O, Utne-Palm A, Ferter K (2014) Toward more efficient longline fisheries: fish feeding behavious, bait characteristics and development of alternative baits. Rev Fish Biol Fisher 24:985-1003

McNeish D (2016) On using Bayesian methods to address small sample problems. Struct Equ Model 23:750-773

Mejuto J, Garcia-Cortes B, Ramos-Cartelle A (2008) Trials using different hook and bait types in the configuration of the surface longline gear used by the Spanish swordfish 
(Xiphias gladius) fishery in the Atlantic Ocean. Col Vol Sci Pap ICCAT 62:1793-1830

MRAG (2008) Field study to assess some mitigation measures to reduce bycatch of marine turtles in surface longline fisheries. Final Report to the Directorate-General for Fisheries and Maritime Affairs. http://ec.europa.eu/ fisheries/documentation/studies/turtle_bycatch_2008_en. pdf. MRAG, London. Accessed 4 Sept 2019

Murtaugh P (2002) Journal quality, effect size, and publication bias in meta-analysis. Ecology 83:1162-1166

Musyl M, Gilman E (2019) Meta-analysis of post-release fishing mortality in apex predatory pelagic sharks and white marlin. Fish Fish. https://doi.org/10.1111/faf.12358

Myers R, Worm B (2003) Rapid worldwide depletion of predatory fish communities. Nature 423:280-283

Nakagawa S, Santos E (2012) Methodological issues and advances in biological meta-analysis. Evolut Ecol 26:1253-1274

Nakagawa S, Poulin R, Mengersen K, Reinhold K, Engqvist L, Lagisz M, Senior A (2015) Meta-analysis of variation: ecological and evolutionary applications and beyond. Methods Ecol Evolut 6:143-152

Pace M, Cole J, Carpenter S, Kitchell J (1999) Trophic cascades revealed in diverse ecosystems. Trends Ecol Evolut 14:483-488

Parga M, Pons M, Andraka S, Rendon L, Mituhasi T, Hall M, Pacheco L, Segura A, Osmond M, Vogel N (2015) Hooking locations in sea turtles incidentally captured by artisanal longline fisheries in the Eastern Pacific Ocean. Fish Res 164:231-237

Peters J, Sutton A, Jones D, Abrams K, Rushton L (2008) Contour-enhanced meta-analysis funnel plots help distinguish publication bias from other causes of asymmetry. J Clin Epidemiol 61:991-996

Petersen S, Ryan P, Underhill L, Goren M (2008) The use of circle hooks to reduce turtle bycatch and their effect on other vulnerable species. In: Petersen S, Nel D, Ryan P, Underhill L (eds) Understanding and mitigating vulnerable bycatch in Southern African trawl and longline fisheries. WWF South Africa Report Series-2008/Marine/002. WWF South Africa, Cape Town, pp 178-184

Petersen S, Honig M, Ryan P, Underhill L, Compagno L (2009) Pelagic shark bycatch in the tuna- and swordfish-directed longline fishery off southern Africa. Afr J Mar Sci 31:215-225

Pfaller J, Chaloupka M, Bolten A, Bjorndal K (2018) Phylogeny, biogeography and methodology: a meta-analytic perspective on heterogeneity in adult marine turtle survival rates. Sci Rep 8:5852. https://doi.org/10.1038/s41598-01824262-w

Piovano S, Balletto E, Di Marco S, Dominici A, Giacoma C, Zannetti A (2004) Loggerhead turtle (Caretta caretta) by catches on long-lines: the importance of olfactory stimuli. Ital J Zool 71:213-216

Piovano S, Farcomeni A, Giacoma C (2012) Effects of chemicals from longline baits on the biting behaviour of loggerhead sea turtles. Afr J Mar Sci 34:1-5

Piovano S, Farcomeni A, Giacoma C (2013) Do colours affect biting behaviour in loggerhead sea turtles? Ethol Ecol Evolut 25:12-20
Polovina J, Abecassis M, Howell E, Woodworth P (2009) Increases in the relative abundance of mid-trophic level fishes concurrent with declines in apex predators in the subtropical North Pacific, 1996-2006. Fish Bull 107:523-531

Reinhardt J, Weaver J, Latham P, Dell'Apa A, Serafy J, Browder J, Christman M, Foster D, Blankinship D (2017) Catch rate and at-vessel mortality of circle hooks versus J-hooks in pelagic longline fisheries. Fish Fish 19:413-430

Robertson G, van den Hoff J (2010) Static water trials of the sink rates of baited hooks to improve understanding of sink rates estimated at sea. SBWG-3 Doc 31. Agreement on the Conservation of Albatrosses and Petrels, Hobart, Australia

Robertson G, Candy S, Wienecke B, Lawton K (2010) Experimental determinations of factors affecting the sink rates of baited hooks to minimise seabird mortality in pelagic longline fisheries. WCPFC-SC6-2010-EB-WP-06. Western and Central Pacific Fisheries Commission, Kolonia, Federated States of Micronesia

Rueda L, Sagarminaga R, Baez J, Camiñas J, Eckert S, Boggs C (2006) Testing mackerel bait as a possible bycatch mitigation measure for the Spanish Mediterranean swordfish longlining fleet. In: Frick M, Panagopoulou A, Rees A, Williams K (Compilers) Book of abstracts of the 26th annual symposium on sea turtle biology and conservation. International Sea Turtle Society, Athens, Greece, p 262

Santos M, Coelho R, Fernandez-Carvalho J, Amorim S (2012) Effects of hook and bait on sea turtle catches in an equatorial Atlantic pelagic longline fishery. Bull Mar Sci 88:683-701

Santos M, Coelho R, Fernandez-Carvalho J, Amorim S (2013) Effects of 17/0 circle hooks and bait on sea turtles bycatch in a Southern Atlantic swordfish longline fishery. Aquat Conserv Mar Freshw Ecosyst 23:732-744

Scharf F, Juanes F, Rountree R (2000) Predator size-prey size relationships of marine fish predators: interspecific variation and effects of ontogeny and body size on trophic-niche breadth. Mar Ecol Prog Ser 208:229-248

Schild A, Voracek M (2015) Finding your way out of the forest without a trail of bread crumbs: development and evaluation of two novel displays of forest plots. Res Synth Methods 6:74-86

Seide S, Röver C, Friede T (2019) Likelihood-based randomeffects meta-analysis with few studies: empirical and simulation studies. BMC Med Res Methodol 19:16

Shomura R (1955) Comparative Study of Longline Baits. Special Scientific Report: Fisheries No 151. U.S Fish and Wildlife Service, Washington, DC

Sibert J, Hampton J, Kleiber P, Maunder M (2006) Biomass, size and trophic status of top predators in the Pacific Ocean. Science 314:1773-1776

Smith S, Rasmussen R, Ramon D, Cailliet G (2008) The biology and ecology of thresher sharks (Alopiidae). In: Camhi MD, Pikitch EK, Babcock EA (eds) Sharks of the open ocean: biology, fisheries and conservation. Blackwell Publishing, Oxford, pp 60-68

SPC (2019) Western and Central Pacific Fisheries Commission Tuna Fishery Yearbook 2018. Oceanic Fisheries Programme, Secretariat of the Pacific Community, Noumea, New Caledonia 
Stokes L, Hataway D, Epperly S, Shah A, Bergmann C, Watson J, Higgins B (2011) Hook ingestion rates in loggerhead sea turtles Caretta caretta as a function of animal size, hook size, and bait. Endanger Species Res 14:1-11

Sutton A, Abrams K, Jones D, Sheldon T, Song F (2000) Methods for meta-analysis in medical research. Wiley, Chichester

Sutton A, Abrams K, Health P (2001) Bayesian methods in meta-analysis and evidence synthesis. Stat Methods Med Res 2802:277-303

Swimmer Y, Gutierrez A, Bigelow K, Barcelo C, Schroeder B, Keene K, Shattenkirk K, Foster D (2017) Sea turtle bycatch mitigation in US longline fisheries. Front Mar Sci. https:// doi.org/10.3389/fmars.2017.00260

Trebilco R, Gales R, Lawrence E, Alderman R, Robertson G, Baker G (2010) Characterizing seabird bycatch in the eastrn Australian tuna and billfish pelagic longline fishery in relation to temporal, spatial and biological influences. Aquat Conserv 20:531-542

Tuyl F, Gerlach R, Mengersen K (2008) Comparison of BayesLaplace, Jeffreys, and other priors: the case of zero events. Am Stat 62:40-44

van Houwelingen H, Arends L, Stijnen T (2002) Advanced methods in meta-analysis: multivariate approach and metaregression. Stat Med 21:589-624

Vetter D, Rücker G, Storch I (2013) Meta-analysis: a need for well-defined usage in ecology and conservation biology. Ecosphere 4:1-24

Viechtbauer W (2010) Conducting meta-analyses in R with the metafor package. J Stat Softw 36:1-48

Wang X, Ryan Y, Faraway J (2018) Bayesian regression modeling with INLA. CRC Press, USA

Ward P (2008) Empirical estimates of historical variations in the catchability and fishing power of pelagic longline fishing gear. Rev Fish Biol Fish 18:409-426
Ward P, Myers R (2005) Shifts in open-ocean fish communities coinciding with the commencement of commercial fishing. Ecology 86:835-847

Ward P, Myers R (2007) Bait loss and its potential effects on fishing power in pelagic longline fisheries. Fish Res 86:69-76

Warraich N (2014) Feeding behavior of loggerhead and leatherback sea turtles: study to better understand longline bycatch. Master of Science Thesis. Florida Atlantic University, Boca Raton, FL

Warraich N, Wyneken J, Blume N (2020) Feeding behavior and visual field differences in loggerhead and leatherback sea turtles may explain differences in longline fisheries interactions. Endanger Species Res 41:67-77

Watson J, Epperly S, Foster D, Shah A (2005) Fishing methods to reduce sea turtle mortality associated with pelagic longlines. Can J Fish Aquat Sci 62:965-981

Wickham H (2016) ggplot2: elegant graphics for data analysis, 2nd edn. Springer, New York

Yokota K, Minami H, Nobetsu T (2006) Research on mitigation of the interaction of sea turtle with pelagic longline fishery in the western North Pacific. In: Proceedings of the 3rd international symposium on SEASTAR2000 and Asian bio-logging science, pp 3-8

Yokota K, Kiyota M, Okamura H (2009) Effect of bait species and color on sea turtle bycatch in a pelagic longline fishery. Fish Res 97:53-58

Yokota K, Mituhasi T, Minami H, Kiyota M (2012) Perspectives on the morphological elements of circle hooks and their performance in pelagic longline fisheries. Bull Mar Sci 88:623-629

Publisher's Note Springer Nature remains neutral with regard to jurisdictional claims in published maps and institutional affiliations. 